\title{
PENGARUH PENDIDIKAN KESEHATAN TERHADAP PENGETAHUAN DAN PERILAKU PEMBERIAN PIJ AT BAYI OLEH IBU DI BRAJ AN TAMANTIRTO BANTUL YOGYAKARTA
}

\section{THE INFLUENCE OF HEALTH COUNSELING TO MOTHERS KNOWLEDGE AND BEHAVIOUR IN GIVING BABY MASSAGE IN BRAJ AN TAMANTIRTO BANTUL YOGYAKARTA}

\author{
Ekawati ${ }^{1}$, Tyasning Yuni Astuti Anggraini²
}

\begin{abstract}
*1Program Studi Kebidanan (D3) Fakultas Kesehatan Universitas Jenderal Achmad Yani Yogyakarta
Jl. Brawijaya Ring Road Barat Ambarketawang, Gamping, Sleman, Yogyakarta 55294,

Email: ekawati_1412@yahoo.com

2 Program Studi Kebidanan (D3) Fakultas Kesehatan Universitas Jenderal Achmad Yani Yogyakarta

Jl. Brawijaya Ring Road Barat Ambarketawang, Gamping, Sleman, Yogyakarta 55294
\end{abstract}

\begin{abstract}
Background: Baby massage is the oldest known human touch therapy and the most popular. Baby massage not only affects the baby's physical and emotional growth. If baby massage done by his father, it can increase milk production in the mother's body.

Objective: Knowing mother's knowledge and behavior about infant massage before and given health education and improvement of knowledge and behavior before and after counseling.

Methods: Type of research that will be used in this research is pre-experiment design (pre-experiment design). The sample size is 30 respondents. Data source in this research is primary data source that is by using questioner and Prior to being given a health education about infant massage.

Result : Knowledge of the majority mother either as many as 19 respondents (63,33\%), after being given health education about baby massage, all knowledge of good mother $(100 \%)$, before given health education about baby massage, infants as a whole fall into the category of less $(100 \%)$ because all mothers do not yet know how to do baby massage, after being given health education about baby massage, mother behavior in doing baby massage majority according to technique that is 17 responden $(56,67 \%)$.

Conclusion: There is a significant influence between health education on infant massage on mother's knowledge and behavior about baby massage in Brajan Tamantirto Banul Yogyakarta
\end{abstract}

Keyword: Baby massage behavior, health education, knowledge.

\section{PENDAHULUAN}

Pijatan bayi merupakan salah satu cara yang menyenangkan untuk menghilangkan ketegangan dan kerewelannya. Karena pijatan lembut akan membantu mengendurkan otot-ototnya, sehingga ia menjadi tenang dan tertidur. Pemijatan terhadap bayi oleh ibunya sendiri juga mempunyai makna sendiri, karena sangat berpengaruh terhadap hubungan batin atau hubungan kejiwaan antara ibu dengan bayi. Bagi sang bayi, pijatan ibu dapat dirasakan sebagai sentuhan kasih sayang yang sangat berarti bagi pembentukan kepribadiannya kelak di kemudian hari. ${ }^{1}$ Melalui sentuhan pemijatan terhadap jaringan otot, peredaran darah dapat meningkat ke jaringan otot ataupun posisi otot dapat dipulihkan dan diperbaiki, sehingga dapat meningkatkan fungsi-fungsi organ tubuh dengan sebaik-baiknya. ${ }^{2}$

Tercapainya pertumbuhan dan perkembangan yang optimal merupakan hasil interaksi berbagai faktor yang saling 
berkaitan, yaitu faktor genetik, lingkungan, dan perilaku, serta rangsangan atau stimulasi yang berguna. ${ }^{3}$

Melalui sentuhan pemijatan kepada bayi, akan menyebabkan berbagai perubahan positif pada bayi. Sentuhan itu akan membuatnya nyaman dan tenang. Dengan melakukan pemijatan yang benar, bayi akan menunjukkan peningkatan nafsu makan dan efektivitas dalam tidur. Selain itu, pemijatan dapat juga memperbaiki kondisi mental, meningkatkan kecerdasan, dan mengasah kemampuan interaksi sosialnya. ${ }^{4}$

Pijat bayi tidak hanya berpengaruh pada pertumbuhan fisik dan emosional bayi. Jika pijat bayi dilakukan oleh ayahnya, maka bisa meningkatkan produksi ASI pada tubuh ibu. Ini dinyatakan dalam suatu penelitian di Australia yang mengatakan bahwa ketika seorang ayah berinisiatif memijat bayi, hal itu akan menimbulkan perasaan positif pada istri. Inisiatif ini akan membuat istri merasa disayang dan nyaman, sehingga akan merangsang produksi oksitosin, di mana hormon ini berguna untuk memperlancar ASI. Penelitian menunjukkan $80 \%$ produksi hormon oksitosin dipengaruhi oleh kondisi psikis ibu. Selain itu, pijat akan membuat bayi cepat lapar sehingga makin banyak ASI yang disedot oleh bayi, maka produksi ASI makin meningkat. ${ }^{5}$

Namun sayangnya masih banyak mitos-mitos di masyarakat khususnya pada perawatan bayi yang tetap dipercaya, contohnya masih banyak ibu-ibu yang enggan untuk melakukan pemijatan secara rutin kepada bayinya, apalagi di awal-awal kelahirannya, karena mereka beranggapan bahwa bayi tidak boleh sering dipijat, badannya masih lemah atau alasan lain yang tidak pernah dibuktikan kebenarannya. Padahal sentuhan pada bayi pada awal-awal kelahirannya bisa memberikan pengaruh positif pada pertumbuhan bayi. ${ }^{6}$ Oleh karena itu, peneliti tertarik untuk melakukan penelitian terkait pengaruh pendidikan kesehatan terhadap pengetahuan dan perilaku pemberian pijat bayi oleh ibu di Brajan Taman Tirto Bantul Yogyakarta.

\section{BAHAN DAN CARA PE NELITIAN}

Jenis penelitian ini adalah pra eskperimen (pre experiment design). Populasi dalam penelitian ini adalah ibu yang memiliki anak usia 0-15 bulan. Teknik pengambilan sampel total sampling dengan jumlah 30 ibu. Total sampling adalah teknik pengambilan sampel di mana jumlah sampel sama dengan populasi. ${ }^{5}$ Analisis data yang digunakan yaitu menggunakan paired t-test.

\section{HASIL DAN PEMBAHASAN}

Tabel 1. Pengetahuan Responden Sebelum Diberi Pendidikan Kesehatan Pijat Bayi

\begin{tabular}{ccc}
\hline Kategori & $\mathbf{F}$ & $\%$ \\
\hline Baik & 19 & 63,33 \\
Cukup & 7 & 23,33 \\
Kurang & 4 & 13,33 \\
\hline Total & $\mathbf{3 0}$ & $\mathbf{1 0 0}$ \\
\hline
\end{tabular}


Tabel 2. Pengetahuan Responden Setelah Diberi Pendidikan Kesehatan Pijat Bayi

\begin{tabular}{ccc}
\hline Kategori & F & $\%$ \\
\hline Baik & 30 & 100 \\
Cukup & 0 & 0 \\
Kurang & 0 & 0 \\
\hline Total & $\mathbf{3 0}$ & $\mathbf{1 0 0}$ \\
\hline
\end{tabular}

Tabel 3. Perilaku Ibu Dalam Melakukan Pijat Bayi Sebelum Diberikan Pendidikan Kesehatan

\begin{tabular}{ccc}
\hline Kategori & F & $\%$ \\
\hline $\begin{array}{c}\text { Sesuai } \\
\text { teknik }\end{array}$ & 0 & 0 \\
Tidak & & \\
sesuai & & \\
teknik & 30 & 100 \\
\hline Total & $\mathbf{3 0}$ & $\mathbf{1 0 0}$ \\
\hline
\end{tabular}

Tabel 4. Perilaku Ibu Dalam Melakukan Pijat Bayi Setelah Diberikan Pendidikan Kesehatan

\begin{tabular}{ccc}
\hline Kategori & F & $\%$ \\
\hline $\begin{array}{c}\text { Sesuai } \\
\text { teknik }\end{array}$ & 17 & 56.67 \\
$\begin{array}{c}\text { Tidak } \\
\text { sesuai } \\
\text { teknik }\end{array}$ & 13 & \\
\hline Total & $\mathbf{3 0}$ & $\mathbf{1 0 0}$ \\
\hline
\end{tabular}

Tabel 5.Tingkat Pengetahuan Ibu Tentang Pijat Bayi Sebelum Dan Sesudah Diberi Pendidikan Kesehatan

\begin{tabular}{|c|c|c|c|c|c|}
\hline Paired Sample t & Pengu & kuran & Selisih & Hasil t & Sig. \\
\hline test & $\begin{array}{l}\text { Pre Test } \\
\text { Mean } \\
\text { (SD) }\end{array}$ & $\begin{array}{c}\text { Post } \\
\text { Test } \\
\text { Mean } \\
\text { (SD) }\end{array}$ & rerata & hitung & \\
\hline $\begin{array}{l}\text { Tingkat } \\
\text { pengetahuan } \\
\text { ibu tentang } \\
\text { pijat bayi } \\
\text { sebelum dan } \\
\text { sesudah diberi } \\
\text { pendidikan } \\
\text { kesehatan }\end{array}$ & $\begin{array}{c}75.93 \\
(12.746)\end{array}$ & $\begin{array}{c}90.55 \\
(5.487)\end{array}$ & 14,62 & $\begin{array}{c}- \\
6.121\end{array}$ & 0,000 \\
\hline
\end{tabular}

\begin{tabular}{|c|c|c|c|c|c|}
\hline \multirow{2}{*}{$\begin{array}{l}\text { Paired } \\
\text { Sample t } \\
\text { test }\end{array}$} & \multicolumn{2}{|c|}{ Pengukuran } & \multirow{2}{*}{$\begin{array}{l}\text { Selisih } \\
\text { rerata }\end{array}$} & \multirow{2}{*}{$\begin{array}{l}\text { Hasil t } \\
\text { hitung }\end{array}$} & \multirow[t]{2}{*}{ Sig. } \\
\hline & $\begin{array}{l}\text { Pre } \\
\text { Test } \\
\text { Mean } \\
\text { (SD) }\end{array}$ & $\begin{array}{l}\text { Post } \\
\text { Test } \\
\text { Mean } \\
\text { (SD) }\end{array}$ & & & \\
\hline $\begin{array}{l}\text { Perilaku } \\
\text { ibu } \\
\text { sebelum } \\
\text { dan } \\
\text { sesudah } \\
\text { diberi } \\
\text { pendidikan } \\
\text { kesehatan } \\
\text { tentang } \\
\text { pijat bayi }\end{array}$ & $\begin{array}{c}0.00 \\
(0.000)\end{array}$ & $\begin{array}{c}57.44 \\
(17.506)\end{array}$ & 57.44 & $\begin{array}{c}- \\
17.973\end{array}$ & 0,000 \\
\hline
\end{tabular}

Berdasarkan hasil penelitian yang dilakukan di Dusun Brajan Desa Tamantirto Kabupaten Bantul Yogyakarta khususnya di dua Posyandu yaitu di Posyandu Widuri A dan Posyandu Widuri B didapatkan bahwa mayoritas ibu memiliki tingkat pengetahuan baik sebanyak 19 responden (63,33\%) sebelum diberikan pendidikan kesehatan tentang pijat bayi dan setelah diberikan pendidikan kesehatan tentang pijat bayi mayoritas ibu memiliki pengetahuan baik $(100 \%)$.

Hasil penelitian ini menunjukkan bahwa setelah diberikan pendidikan kesehatan tentang pijat bayi ibu memiliki peningkatan pengetahuan. Hal ini kemungkinan pada saat diberikan pendidikan kesehatan ibu dapat menerima materi dengan baik, dan peneliti menggunakan media leaflet yang menarik yang selanjutnya bisa dibawa pulang oleh ibu dan dapat dipelajari kembali sehingga pengetahuan ibu mengalami peningkatan. Penyuluhan 
kesehatan merupakan kegiatan pendidikan kesehatan yang dilakukan dengan cara menyebar pesan, menanamkan keyakinan sehingga masyarakat tidak hanya sadar, tahu, dan mengerti tetapi juga mau melakukan tindakan yang ada kaitannya dengan kesehatan. ${ }^{8}$ Penginderaan terhadap objek dapat diperoleh melalui berbagai cara yaitu pendidukan formal, pengalaman, latihan, maupun kursus. Hal ini juga berkaitan dengan kemampuan untuk mengingat materi yang bersifat teoritis maupun praktik yang diberikan. Pengetahuan atau kognitif merupakan sesuatu yang dominan untuk terbentuknya tindakan seseorang dan mengubah pengetahuan, sikap dan perilaku adalah dengan pendidikan dan latihan. ${ }^{9}$

Hasil penelitian tentang perilaku pijat bayi menunjukkan bahwa secara keseluruhan responden tidak sesuai dengan teknik ketika melakukan pijat bayi, karena belum mendapatkan informasi tentang pijat bayi dan mereka biasa melakukan pijat bayi di dukun bayi. Setelah mendapatkan pendidikan kesehatan tentang pijat bayi mayoritas responden melakukan pijat bayi sesuai dengan teknik yaitu 17 responden (56,67\%). Hal ini kemungkinan karena ibu belum pernah terpapar atau mendapatkan informasi tentang pijat bayi yang dilakukan oleh ibu sendiri, karena mayoritas responden melakukan pijat bayi di dukun bayi. Keterampilan seseorang dapat ditentukan oleh pengetahuan, sikap, dan ketersedian fasilitas dan perilaku petugas kesehatan sebagai fasilitator kesehatan. ${ }^{10}$ Hasil penelitian ini sesuai dengan penelitian Mawar tahun 2011 dengan judul Pengaruh penyuluhan teknik pijat bayi terhadap pengetahuan dan keterampilan ibu dalam melakukan pijat bayi di Dusun Mertosanan Potorono Banguntapan Bantul Yogyakarta.

\section{KESIMPULAN}

Sebagian besar responden memiliki pengetahuan baik sebanyak 19 responden $(63.33 \%)$ sebelum dilakukan pendidikan kesehatan pijat bayi dan setelah diberikan pendidikan kesehatan seluruh responden memiliki pengetahuan baik (100\%). Semua responden (100\%) memiliki perilaku yang tidak sesuai dengan teknik pijat bayi sebelum diberikan pendidikan kesehatan, dan setelah dilakukan pendidikan kesehatan tentang pijat bayi sebagian besar ibu memiliki perilaku yang sesuai dengan teknik pijat bayi sebanyak 17 responden (56.67\%).

Ada pengaruh yang signifikan antara pendidikan kesehatan tentang pijat bayi terhadap pengetahuan ibu tentang pijat bayi di Brajan Tamantirto Bantul Yogyakarta. Ada pengaruh yang signifikan antara pendidikan kesehatan tentang pijat bayi terhadap perilaku ibu dalam melakukan pijat bayi di Brajan Tamantirto Bantul Yogyakarta.

Berdasarkan hasil tersebut, diharapkan ibu mau menerapkan praktik pijat mandiri secara rutin kepada anaknya, serta dapat memerikan edukasi kepada ibu-ibu lainnya. 


\section{TERIMA KASIH}

1. Prof. H. Mohamad Nasir, Ph.D., Ak. Menteri Riset Teknologi dan Pendidikan Tinggi Repulik Indonesia, email: menristekdikti@ristek.go.id

2. Kuswanto Hardjo, dr., M.Kes. Dekan Fakultas Kesehatan Universitas Jenderal Achmad Yani Yogyakarta.

\section{KEPUSTAKAAN}

1. Roesli, Utami. Pedoman Pijat Bayi, Cetakan Kesepuluh. Edisi Revisi. Jakarta: PT. Trubus Agriwidya; 2008.

2. Panji, Mohammad. Pertumbuhan Berat Badan Bayi. 2003. [1 April 2015]. Diakses Dalam http://fordearest.wetpaint.com/page/berat +badan+dan+tabel+pertumbuhan.

3. Subakti, Z. Keajaiban Pijat Bayi. Jakarta: Wahyu Media. 2009.
4. Kusnandi, Rusmil. Pertumbuhan dan Perkembangan Anak. 2008. [1 April 2015] Diakses Dalam: http://translate.google.co.id/translate?hl=i d\&langpair=en|id\&u=http://www.kellymom .com/babyconcerns/growth/weightgain.html.

5. Widyani, Widyastuti. Pedoman Perawatan Bayi. 2007. [1 April 2015 ]. Diakses Dalam http://www.anneahira.com/perawatanbayi/.htm.

6. Sugiyono. Metode Penelitian Kuantitatif Kualitatif dan $R$ dan D. Bandung: Alfabeta; 2007.

7. Rahayu, Asti. Pedoman Merawat Bayi. Jakarta : Erlangga; 2005.

8. Notoatmodjo, S. Pendidikan dan Perilaku kesehatan. Jakarta : PT Rineka Cipta; 2003.

9. Notoatmojo, S. Metodologi Penelitian Kesehatan. Jakarta: Rineka Cipta; 2007.

10. Arikunto, S. Prosedur Penelitian Suatu Pendekatan Praktik. Jakarta : PT Rineka Cipta; 2006. 